\title{
ARIDITY INDEX AND CLIMATIC RISK OF DESERTIFICATION IN THE SEMI-ARID STATE OF SERGIPE
}

\author{
JESUS, Janisson Batista de - janisson.eng@gmail.com \\ Universidade Federal do Sergipe / UFS \\ SOUZA, Bruno Barros de - brunobarros.eco@gmail.com \\ Instituto do Meio Ambiente e Recursos Hídricos \\ OLIVEIRA, Alisson Marcel Souza de - alisson182001@yahoo.com.br \\ Universidade Federal do Sergipe / UFS \\ GAMA, Drauzio Correia - drauziogama@hotmail.com \\ Universidade Estadual do Sudoestes da Bahia / UESB
}

\begin{abstract}
The semi-arid is a region of high temperatures and low rainfall conditions, and can be the gateway to the establishment of climatic processes that aggravate this aridity condition. The objective of the present study was to identify the areas most susceptible to desertification in the semi-arid state of Sergipe, through the application of the aridity index. The aridity index was generated from the input monthly data of precipitation and temperature, and the classification of the index was performed in: hyperarid, arid, semi-arid, sub-humid dry and sub-humid and humid, with a subsequent classification of the risk level as being very high, high and moderate. The semi-arid region of the state of Sergipe has all the superior extension in prominence, since it shows the highest aridity index (reaching 0.09 in Canindé de São Francisco and Poço Redondo) and, consequently, higher risk to desertification, especially the northwest with a classification of semiarid. Monthly, there is a condition of aridity in some regions, which magnifies the susceptibility to the processes of desertification.
\end{abstract}

KEYWORDS: climate classification, aridization, Caatinga.

ÍNDICE DE ARIDEZ E RISCO CLIMÁTICO À DESERTIFICAÇÃO DO SEMIÁRIDO DO ESTADO DE SERGIPE

RESUMO: O semiárido é uma região de altas temperaturas e baixas condições pluviométricas, podendo ser a porta de entrada para o estabelecimento de processos climáticos que agravem essa condição de aridez. O objetivo do presente estudo foi identificar as áreas mais susceptíveis à desertificação no semiárido do estado de Sergipe, através da aplicação do índice de aridez. O índice de aridez foi gerado a partir dos dados de entrada de precipitação e temperatura mensal, sendo realizada a classificação do índice em: hiper-árido, árido, semiárido, subúmido seco e, subúmido e úmido, com posterior enquadramento do nível do risco em muito alto, alto e moderado. O semiárido do estado de Sergipe tem toda a extensão superior em destaque, pois demonstra os maiores índices de aridez (chegando a 0,09 em Canindé de São Francisco e Poço Redondo) e, consequentemente, maior risco à desertificação, em especial no Noroeste, com uma classificação de semiárida. Mensalmente, existe ocorrência de condição de aridez em algumas regiões, o que magnifica a susceptibilidade aos processos de desertificação.

PALAVRAS-CHAVE: classificação climática, aridização, Caatinga.

\section{INTRODUCTION}

Desertification is a phenomenon of global relevance, recognized by the United Nations Convention to Combat Desertification (UNCCD) as the process of 
land degradation in the arid, semi-arid and dry sub-humid regions, produced by several factors including climatic variations and human activities, which since 1997 is a signatory to Brazil, making important commitments regarding the monitoring and mitigation of its effects (MMA, 2007).

The semi-arid region of northeastern Brazil is the region most vulnerable to the effects promoted by desertification throughout the country (LIMA et al., 2011). The Caatinga biome, which makes up such geographical space, is one of the most susceptible to the scenario of increasing global temperatures, whose stability is impacted by climate changes and, consequently, becoming a region of alert for this process (OYAMA and NOBRE, 2003), since the increase of the temperature together with the suppression of the vegetation favors the occurrence of aridization and desertification (GUIMARÃES et al., 2016).

It is noteworthy that the climatic condition influences the desertification process in the northeastern semi-arid region, so that the factors that interfere in the climate can also be raised as favoring changes in soil dryness levels, which denotes the complexity of this climatic phenomenon. Cunha et al. (2015) observed that, even on a small scale, changes in land use and land cover in this region of the country were seen as an element capable of causing impacts on the climate at local and regional scale, and that changes in land cover could still influence the climatic processes on a large scale in view of changes in energy, water, carbon and atmospheric circulation.

At the regional level, the Brazilian northeast presents a high conversion of its natural vegetation to agricultural regions, altering, consecutively, the conformation of land use and cover, which indicates the strong pressure of the anthropic activity in this territory and the necessity of the inclusion of public policies and integrated management of a large region of Brazil, since there are climatic implications related to land use and land use dynamics (RITA et al., 2013).

The susceptibility to the desertification process in the Brazilian semi-arid region has a moderate to high variation, and in the climatic context, areas with wet and sub-humid classification have low vulnerability, however, when considering problems related to land use management areas are prone to degradation, which may facilitate the desertification process (RITA et al., 2015). Throughout the northeast of Brazil, there are several areas with a high level of environmental degradation that should be considered as priorities for governmental intervention in order to combat the installation of desertification. Among the many sites, the Sergipe High Sertão region deserves to be highlighted in the state, based on measures that minimize the impacts of climate change, changes in aridity levels and changes in soil cover (TOMASELLA et al., 2018).

Considering the problems related to this process, one of the simplest and most applied methodologies is the use of the level of susceptibility to desertification based on aridity index (AI), proposed by Matallo Júnior and Schenkel (2003), which has three categories of susceptibility (Very High, High and Moderate), which is the standard applied to the National Plan to Combat Desertification (LOPES and LEAL, 2015).

Climatic indices, such as aridity, are proposed for the climatic characterization of a given area since, in this case, it is obtained through variables of the water balance and potential evapotranspiration, indicating the local climatic 
conditions to which strategies and planning for sustainable development can be established, aiming at the most appropriate management of natural resources (FRANCISCO et al., 2015b).

The elaboration of this index of aridity through the Thornthwaite equations includes, as an element of climate classification, besides the rainfall and air temperature, potential evapotranspiration, thus relating the water requirements or the amount of water needed to supply the demand of evapotranspiration (BARROS et al., 2012). In addition, it takes into account the ecological climate, representing a greater effort to systematize through potential and real evapotranspiration formulas, designing a climatic classification with an innovative and constructive aspect (FRANCISCO et al., 2015a) that can be calculated by the Climatological Water Balance (CWB) proposed by Thornthwaite and Mather (1955).

The aridity index is widely used in studies for the delimitation of dry areas (RIBEIRO et al., 2016, SANTOS et al., 2016; CABRAL JÚNIOR and BEZERRA, 2018; SILVA et al., 2019) and in determining the vulnerability to desertification because it is considered of great precision in the characterization of these areas, since is the only one in which the analysis uses quantitative variables (SAMPAIO and SAMPAIO, 2002) and its calculation indicates exactly the climatic condition to be analyzed (Santos et al., 2016).

Considering the relevance of the climatic classification and delimitation of the areas vulnerable to desertification in the Brazilian semi-arid region, it is necessary to monitor the climatic condition of this region, verifying the level of aridity over time and observing if there is an increase in the susceptibility to this phenomenon. In the state of Sergipe, there are no specific studies that provide this information in detail, even almost half of its territory being in the semi-arid region and already having a region defined as a priority for measures to protect the desertification process.

In this way, the present study aimed to identify the areas most susceptible to the climatic risk of desertification for the semi-arid region of the State of Sergipe, by applying the aridity index from the data generated by the Thornthwaite and Mather method.

\section{MATERIAL AND METHODS}

The study area is characterized as the semi-arid portion of the State of Sergipe, Brazil, which includes 29 municipalities and encompasses about $51 \%$ of the territory according to the Semi-Arid National Institute (INSA, 2019) (Figure 1), making a border with federal entities of Bahia and Alagoas, and is under the control of all existing Hydrographic Basins in the state (Real River, Piauí, VazaBarris, Sergipe River, Japaratuba River, São Francisco River) with the exception of Costeiras 1 and 2. It has the caatinga as typical vegetation and BSh climate according to the classification of Köppen, considered hot semi-arid, with low rainfall incidence, which varies between 250 and $900 \mathrm{~mm}$ annually (EMBRAPA, 
2017).

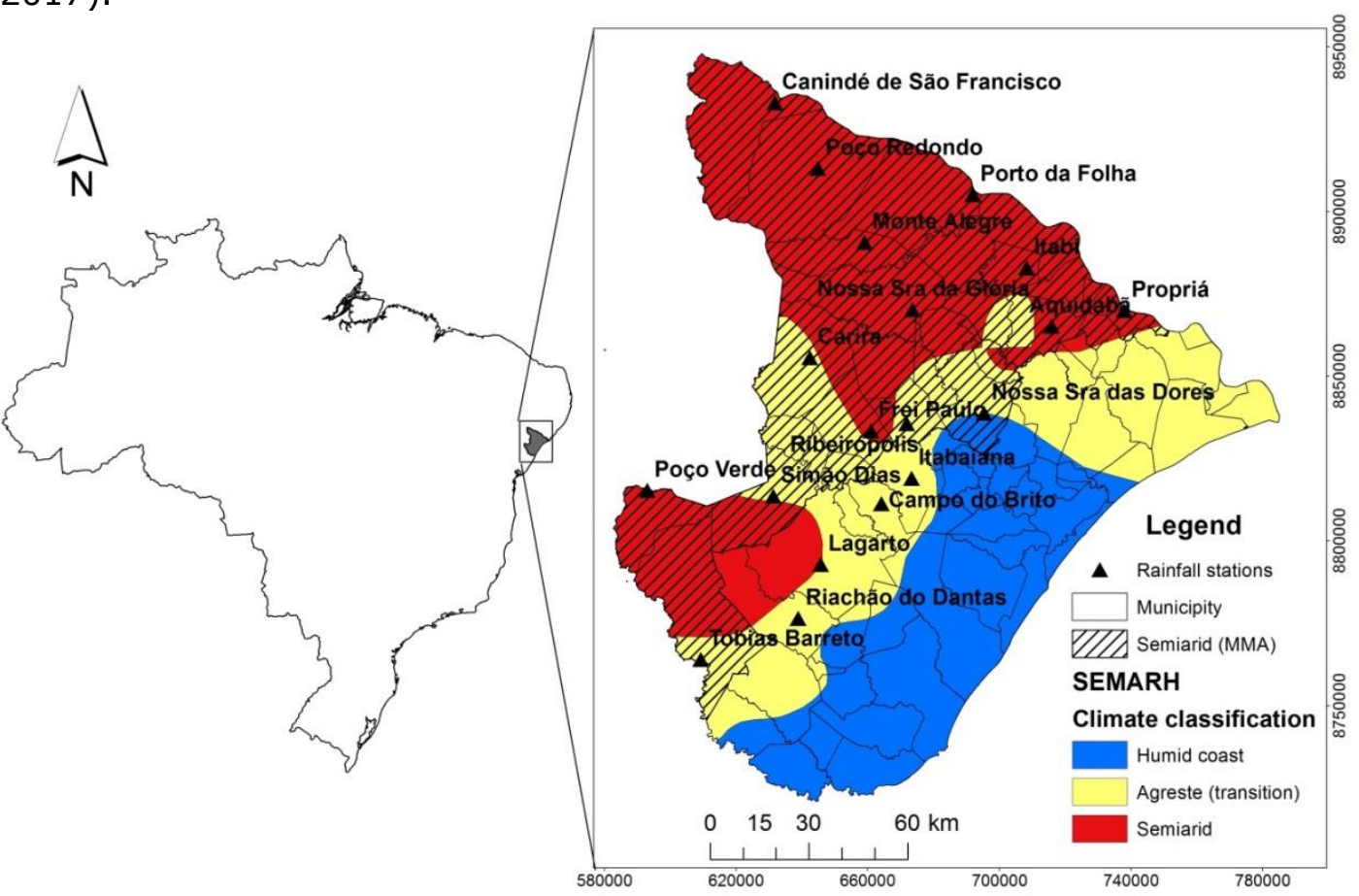

Figure 1 - Location of the study area, with distribution of the rainfall stations used, and the climatic delimitations of the State Secretariat of Environment of the State of Sergipe (SEMARH) and INSA (2019).

The aridity index (AI) was generated according to the equation suggested by UNESCO (1979), based on the relationship between rainfall and potential evapotranspiration, obtained through the calculations of the Climatological Water Balance proposed by Thornthwaite and Mather (1957, as described below:

$$
\mathrm{AI}=\mathrm{Pr} / \mathrm{ETp}
$$

Where: AI: aridity index; Pr: rainfall and ETp: potential evapotranspiration.

The monthly cumulative rainfall data were acquired from 19 rainfall stations distributed throughout and close to the semi-arid region of Sergipe under operation of DNOCS, DNOS, Sudene and EMDAGRO, from the year 1950, in order to be compatible with the temperature data that were estimated using the software Estima_T, prepared by the Department of Atmospheric Sciences of Campina Grande, State of Paraíba, Brazil, which initially generates the series as of this year. The selected time series considered the years taking into account the absence of failure to record precipitate volume. As for temperature, the series of data is completely complete as it is the result of the calculations of your estimate. In addition, due to the lack of a complete record of rainfall for the region, 8 stations had the beginning of the series in 1963. The time series used was completed until the year 2016, except for the stations of Campo do Brito, Itabi and Tobias Barreto, which recorded data until 2005, 2012 and 2013, respectively, and the first two belonged to the stations previously mentioned.

The temperature database followed the same series of rainfall, by which the model of this computational program executes the estimation of the time 
series of the mean, maximum and minimum monthly air temperature according to the geographic coordinates (i.e., latitude, longitude and altitude) and the monthly time series of Sea Surface Temperature Anomalies (ATSM) of the Tropical Atlantic Ocean for the month and year considered, using an empirical model of quadratic function (Cavalcanti et al., 2006) given by:

$\mathrm{T}_{\mathrm{ij}}=\mathrm{a}_{0}+\mathrm{a}_{1} \lambda+\mathrm{a}_{2} \phi+\mathrm{a}_{3} \mathrm{~h}+\mathrm{a}_{4} \lambda^{2}+\mathrm{a}_{5} \phi^{2}+\mathrm{a}_{6} \mathrm{~h}^{2}+\mathrm{a}_{7} \lambda \phi+\mathrm{a}_{8} \lambda \mathrm{h}+\mathrm{a}_{9} \phi \mathrm{h}+$ ATSM $_{\mathrm{ij}}$ where: $\lambda$ is longitude, $\phi$ is latitude, in degrees; $h$ is the elevation (altitude) of each weather station analyzed, in meters; and $a_{0}, a_{1}, \ldots, a_{9}$ are the regression coefficients. The indices $i$ and $j$ indicate respectively the month and year for which the air temperature $\left(T_{i j}\right)$ is being calculated.

Then, for the data of each rainfall station, the climatological water balance was calculated and the climatic classification of the aridity index was performed by means of the classes adopted by CONAMA 238 (Table 1), then the risk to desertification was determined by the National Plan to Combat Desertification according to Matallo Júnior and Schenkel (2003), also adopting the adaptation of Lopes et al. (2017) according to Table 2.

Table 1 - Classes of variation of aridity index.

\begin{tabular}{cc}
\hline Classes & Index \\
\hline Hyper-arid & $<0,05$ \\
\hline Arid & $0,05-0,20$ \\
\hline Semi-arid & $0,21-0,50$ \\
\hline Sub-humid dry & $0,51-0,65$ \\
\hline Sub-humid and humid & $>0,65$
\end{tabular}

Table 2 - Classes of risk to desertification from the aridity index.

\begin{tabular}{cc}
\hline $\begin{array}{c}\text { Aridity } \\
\text { index }\end{array}$ & $\begin{array}{c}\text { Level of risk to } \\
\text { desertification }\end{array}$ \\
\hline$<0,05$ & Higher to very high \\
\hline $0,05-$ & Very high \\
0,20 & High \\
\hline $0,21-0,5$ & Moderate \\
\hline $0,51-$ & \\
0,65 & Less than moderate \\
\hline$>0,65$ &
\end{tabular}

The spatial interpolation of the data generated for the semi-arid region of Sergipe was performed in the ArcGIS 10.2.2 by the Inverse Distance Weighting method (IDW), starting from the annual average as well as the monthly averages of the historical series analyzed based on the geographic point of the measurement stations used. This method was chosen as well as being a widely used geospatial estimator, it did not modify the minimum and maximum values of the series of data used, while the other interpolators were changing these 
values, which would mean changing the mean values to obtain the indexes worked.

\section{RESULTS AND DISCUSSION}

The analysis of the annual mean of the data of entry for the study indicates a compatibility of the regions with smaller means of rainfall with higher temperatures in all upper part of the semi-arid of the State of Sergipe (Figure 2), with specific emphasis in the municipalities of Canindé de São Francisco, Poço Redondo and Porto da Folha. Another similarity can be seen in the portion tending to the coast of the state, which presents higher amounts of rainfall at the same time as it does not have high average annual temperatures.

The temperature spatialization showed a more uniform behavior along the semi-arid region of Sergipe, with lower fluctuations among the lower temperatures, which are distributed throughout the semi-arid region of Sergipe, excluding exactly the upper portion where it is superior among the highest. Considering also this region, a direct proportional relationship between rainfal and historical average temperature is observed, with the lowest values seen along the entire western portion of the territory, while the highest ones are arranged in the inverse region, where it is located the agreste of the state.

The annual results show that in the region studied, only in the northwest of the state, there is a semi-arid condition, which in turn presents a high risk to desertification, surrounded by a significant dry sub-humid area, as well as in the southern end and southwest, with a moderate susceptibility (Figure 2). Most of the analyzed area has a sub-humid and humid climatic classification that has a lower risk to the effects of desertification.

Even though the State of Sergipe does not have a significant area associated with aridity, the semi-arid region of northeastern Brazil presents statistically significant trends of increase in aridity conditions, which indicate that it can become a major desertification process area (LOPES et al., 2017), and there should be greater attention in this area, with monitoring and measures to protect the environment, since environmental degradation is almost always tied to anthropic or even natural activities (RIBEIRO et al., 2016). Moreover, it is necessary to focus on the conservation of the caatinga, since aridity is the characteristic of the climate that relates insufficient rainfall to maintain a vegetation, and that associates the amount of water precipitated and the maximum possible loss of water through evaporation and transpiration (ALVES et al., 2012). 

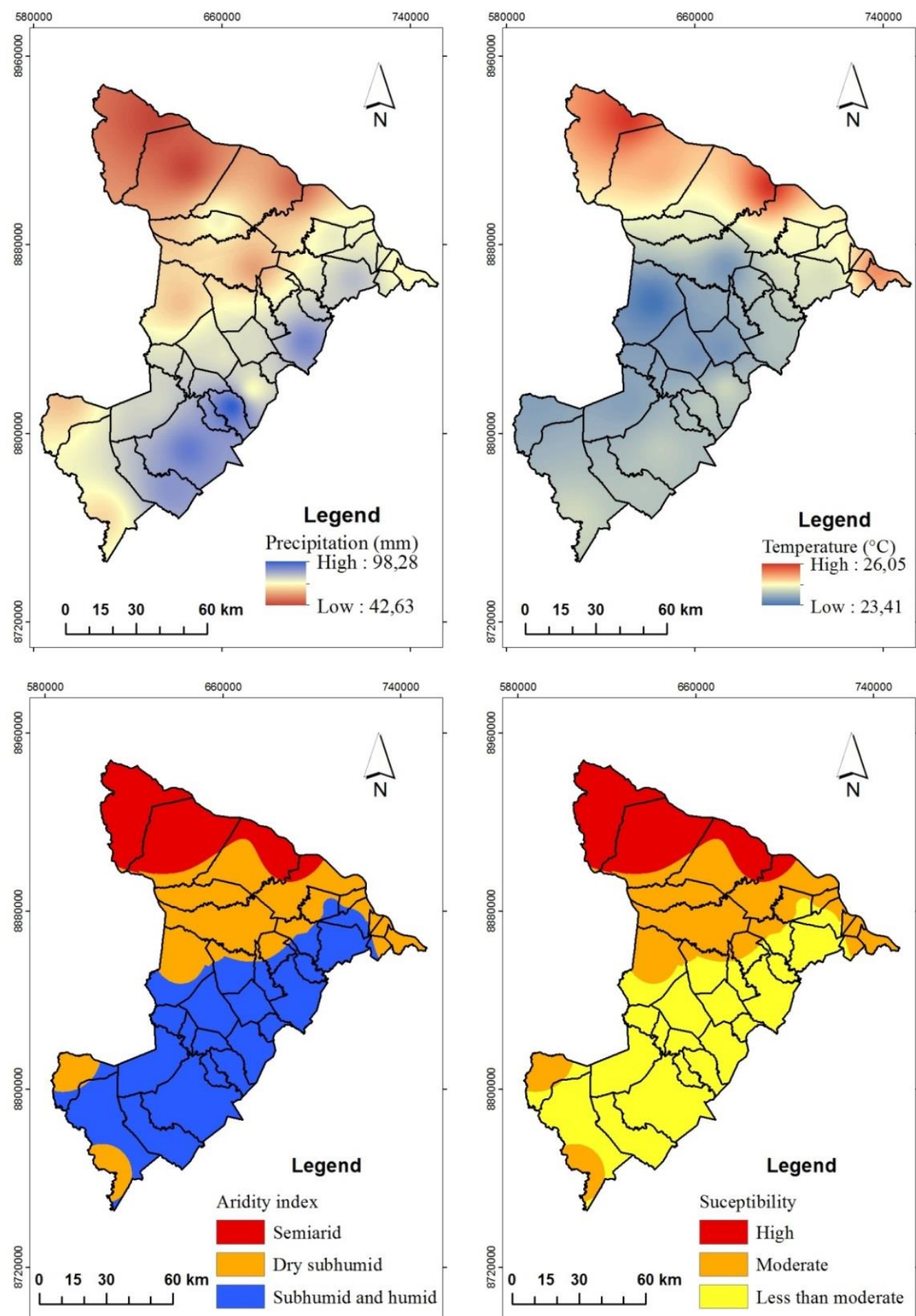

Figure 2 - Spatial distribution of the monthly average annual precipitation $(\mathrm{mm})$, temperature $\left({ }^{\circ} \mathrm{C}\right)$, and the aridity index and susceptibility to desertification in the semiarid state of Sergipe.

Despite this annual classification indicating that most of the territory is classified at most a moderate susceptibility, it is noted that monthly there is a 
great variation of these climatic classes throughout the year as listed in Table 3, which in general indicates that in the months of October to March, the localities have a semi-arid condition, with an even greater emphasis on some municipalities with a classification of aridity, associated to the last months of the year, as seen mainly in Canindé de São Francisco, Poço Redondo, Porto da Folha, Monte Alegre, Itabi, located in the portion of Sergipano High Sertão, and even the municipalities of Aquidabã, Itabaiana and Propriá that are closer to the coast. Between the months of April and August, there is a reduction in the level of aridity in the semiarid region of Sergipe, with almost all the municipalities reaching a subhumid and humid index with values above 1 . Despite this, it is observed that even in this period, in Canindé de São Francisco, Poço Redondo and Porto de Folha, these values are much lower, indicating the low water conditions of these localities even in the rainy season, which places these municipalities in a situation of alertness regarding the aridity and risk index of of desertification.

Table 3 - Monthly values of the aridity indices generated as a function of each rainfall station and respective municipality studied.

\begin{tabular}{|c|c|c|c|c|c|c|c|c|c|c|c|c|}
\hline $\begin{array}{l}\text { Rainfall } \\
\text { station }\end{array}$ & an & feb & mar & apr & may & jun & jul & aug & sep & oct & nov & dec \\
\hline Aquidabã & 29 & .32 & .55 & 1.05 & 63 & 1.74 & 1.79 & .19 & .66 & 0.36 & .23 & 0.1 \\
\hline $\begin{array}{l}\text { Campo do } \\
\text { Brito }\end{array}$ & .36 & .45 & .57 & & 1.81 & 2.16 & 2.41 & 1.69 & 0.85 & 0.45 & 0.37 & 0.29 \\
\hline Canindé & .28 & .26 & .33 & 0.45 & 0.58 & 0.72 & 0.73 & 0.38 & 0.18 & 0.09 & 0.10 & 0.21 \\
\hline Carira & & & & & 1.12 & 1.50 & 1.55 & 7 & & 0.2 & 0.2 & 0.28 \\
\hline $\begin{array}{l}\text { Senhora da } \\
\text { Dores }\end{array}$ & & & & & & 2.14 & & & & & 0.27 & 0.23 \\
\hline aulo & & & & & & 1.74 & 1.71 & & & 0.36 & 0.26 & 0.28 \\
\hline a da & 0.31 & 0.34 & 0.41 & 0.76 & 1.01 & 1.26 & 1.45 & 0.78 & 0.43 & 0.28 & 0.21 & 0.26 \\
\hline רa & 0.22 & 0.29 & 0.41 & 0.92 & 1.37 & 1.61 & 1.63 & 1.19 & 0.60 & 0.34 & 0.24 & 0.16 \\
\hline Itabi & 0.22 & 0.28 & 0.46 & 0.95 & 1.37 & 1.73 & 1.77 & 1.11 & 0.63 & 0.24 & 0.13 & 0.19 \\
\hline Lagarto & 0.34 & 0.49 & 0.64 & 1.17 & 1.74 & 1.89 & 2.03 & 1.29 & 0.74 & 0.44 & 0.41 & 0.32 \\
\hline $\begin{array}{l}\text { Monte } \\
\text { Alegre }\end{array}$ & 0.38 & 0.31 & 0.51 & 0.79 & 1.20 & 1.81 & 1.97 & 0.91 & 0.49 & 0.28 & 0.19 & 0.21 \\
\hline $\begin{array}{l}\text { oço } \\
\text { edondo }\end{array}$ & 0.33 & 0.29 & 0.34 & 0.49 & 0.61 & 0.78 & 0.81 & 0.39 & 0.22 & 0.09 & 0.15 & 0.21 \\
\hline Poço Verde & 0.30 & 0.34 & 0.61 & 0.74 & 1.15 & 1.30 & 1.34 & 0.91 & 0.27 & 0.25 & 0.31 & 0.35 \\
\hline $\begin{array}{l}\text { Porto da } \\
\text { Folha }\end{array}$ & 0.22 & 0.21 & 0.38 & 0.51 & 0.76 & 0.83 & 0.92 & 0.48 & 0.23 & 0.16 & 0.13 & 0.10 \\
\hline Propriá & 0.22 & 0.25 & 0.40 & 0.84 & 1.26 & 1.42 & 1.40 & 0.81 & 0.47 & 0.26 & 0.18 & 0.21 \\
\hline $\begin{array}{l}\text { Riachão do } \\
\text { Dantas }\end{array}$ & 0.32 & 0.57 & 0.61 & 0.99 & 1.51 & 1.84 & 1.84 & 1.38 & 0.76 & 0.46 & 0.38 & 0.30 \\
\hline Ribeirópolis & 0.27 & 0.35 & 0.44 & 0.94 & 1.56 & 1.82 & 1.98 & 1.31 & 0.67 & 0.35 & 0.30 & 0.24 \\
\hline Simão Dias & 0.33 & 0.41 & 0.56 & 0.95 & 1.39 & 1.75 & 1.76 & 1.32 & 0.59 & 0.35 & 0.33 & 0.35 \\
\hline $\begin{array}{l}\text { Tobias } \\
\text { Barreto }\end{array}$ & 0.26 & 0.38 & 0.55 & 0.79 & 1.19 & 1.20 & 1.21 & 0.81 & 0.43 & 0.34 & 0.30 & 0.38 \\
\hline
\end{tabular}


Analyzing data from meteorological stations in some cities in the states of Bahia and Pernambuco, Lopes and Leal (2015) observed that although Salvador, Recife, Bom Jesus da Lapa and Cabrobó present a small temporal trend towards the desertification process, however Garanhuns and Lençóis have a greater tendency, which results in the increase of the level of aridity in these localities. Santos et al. (2016) also identified high susceptibility to desertification in 7 of the 8 cities in the Bahia, Pernambuco and Piauí, only in Senhor do Bomfim (Bahia) was observed a moderate classification. In the state of Paraíba, Ribeiro et al. (2016) also verified the temporal and spatial variation of the degree of risk of desertification in the Umbuzeiro microregion, even though with values of the aridity index indicating moderate to very high risk of occurrence of the process. The response of these different localities shows that there is a spatial variation of the climatic vulnerability to the risk of desertification in northeastern Brazil, as well as temporal, as confirmed in the present study in the semi-arid region of the state of sergipe, with specific periods having low values aridity index and others with higher values, depending on the rainfall supply.

Cabral Júnior and Bezerra (2018) analyzed the reference evapotranspiration and the aridity index for the entire Brazilian northeast and observed that the subregion that includes the semi-arid region of the state of Sergipe presented the highest reference evapotranspiration values between the months of October to March, under the effect of the summer season, as seen in the present study, being this condition a possible contributor for the intensification of the droughts.

The aridity index seasonally spawned by the authors also showed similarity to those generated monthly in Figure 3, showing that the critical months for the aridity condition are the same as mentioned above. As a result of this monthly observation, the risks to desertification also have another conformation regarding the annual spatialisation. Although the results of the annual averages show a small area of high risk, when analyzing the historical series by month, it is noticed that in 7 months of the year there is a totality or significant occurrence of high susceptibility (September to March), with emphasis on the last 4 months of the year, influenced by lower amounts of rainfall, with a high risk incidence mainly in November, where the whole northern extension is more vulnerable, with greater expansion in the northwest of the semi-arid region. Already during the months of April to August there is a low risk of aridization along the semi-arid territory of the state, with the presence of only the north and north-west sections, which is considered the State's High Sertão, where the municipalities are located of lower aridity rates.

The northwestern portion influenced mainly by the low rainfall and high temperature in Canindé de San Francisco has a delicate situation that, during almost all the year, presents at least moderate risk, excluding only the months of June and July that present the highest monthly average rain. In these months, it is also verified that in all the semi-arid there is no vulnerability to the occurrences of desertification, since it is the period of lower temperatures and higher rainfall rates that eliminate the risk for the whole area. The eastern and southeastern regions of Sergipe have the least influence of the climatic processes of desertification during the middle of the year, but in the other months they are conditioned to a variation of moderate to high risk, and presenting less time under the action of climate regimes that intensify the vulnerability to this risk. 

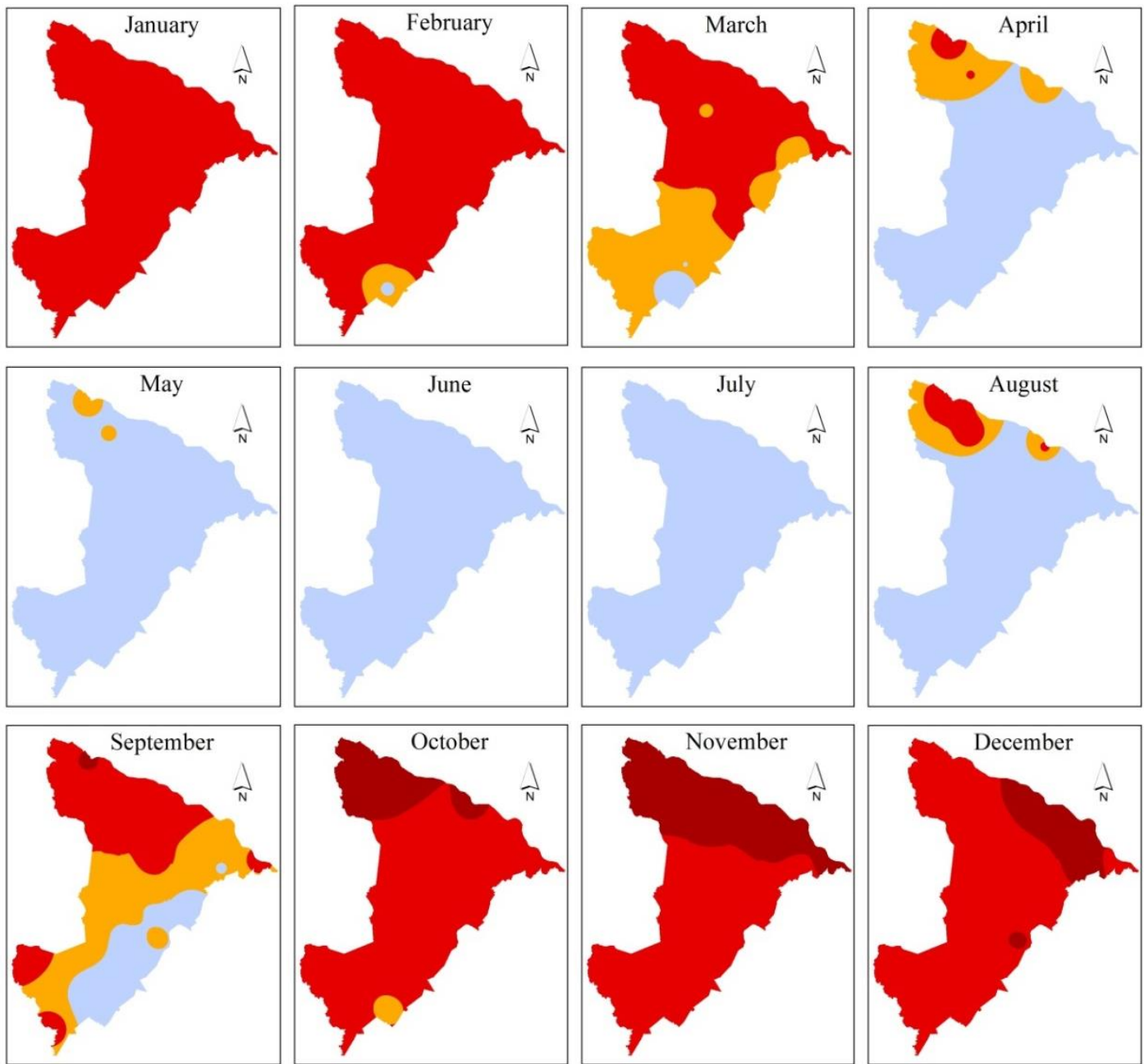

\section{Legend}

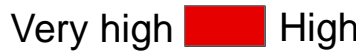

Moderate

Less than moderate

Figure 3 - Monthly vulnerability to the risk of aridity in the semi-arid state of Sergipe.

Comparing monthly the level of aridity in the studied municipalities (Table 3) and the susceptibility to desertification (Figure 3) spatialized along the semiarid with precipitation in the state of Sergipe as verified by Lundgren et al. (2017b), it is noted that there is more aridity and respective climatic susceptibility to the desertification process in regions with smaller precipitated volumes. According to the aforementioned authors, there is a decrease of the precipitations from the coast to the interior and a gradual increase in the average values from April to July, and later reduction, with low values over the months.

This information highlights the relationship between deficiency and water surplus at different times of the year, through climatic elements (air temperature and rainfall), which reflect directly on the water balance, associated to aridity and vulnerability to desertification processes, which in turn affects the response of 
vegetation and its environmental conservation conditions (Carvalho et al., 2011), as well as the agricultural production and way of life of the population.

\section{CONCLUSIONS}

The semi-arid region of the State of Sergipe has specific areas with higher and lower rainfall and temperature, with most of the territory presenting a moderate risk to desertification, and greater expressiveness of the sub-humid and humid class, while the higher values referring to the aridity index and, consequently, risk of desertification, occur especially in the northwest, in a semiarid classification.

There is spatial variability regarding the classification of aridity in the semiarid region of Sergipe, mainly in the monthly temporality, where it is identified the periods throughout the year with greater and lesser susceptibility to the processes of desertification, even reaching a condition of aridity in some regions.

Therefore, this study allowed to identify the areas that need greater visibility for the issues of protection of the sergipan semi-arid region against climate change and anthropic actions, in order to reduce impacts and minimize local aridization. In addition, greater conservation practices of the region, of the agricultural activities, and of the preservation of the Biome caatinga are needed in order to maintain its resilience in order to reduce the effects of semiarid aridity and possible desertification processes.

Thus, permanent studies on the changes in aridity levels of the semi-arid state of Sergipe are indicated, since it is at risk of desertification, with other methodologies, with larger series, or analyzing each location in a more complex way, or including other factors in the analysis, since this methodology is simple and only adopts the climatic condition to assess vulnerability to desertification, which limits its association with the dynamics of land cover.

\section{REFERENCES}

ALMEIDA, J. B. de; MOREIRA, A. A.; FERNANDES, F. H. S.; ALMEIDA, R. P. de; NERY, C. V. M. O sensoriamento remoto aplicado ao estudo da desertificação na região semiárida do norte de Minas Gerais. Revista Brasileira de Geomática, Curitiba, v. 2, n. 2, p. 31-39, 2014.

ALVES, J. J. A., SILVA, M. C. da, SILVA, V. dos S.; CARVALHO, V. C. de. Indicadores climáticos das áreas de desertificação nos cariris velhos da Paraíba. Revista Geonorte, Manaus, edição especial 2, v. 1, n. 5, p. 585-597, 2012.

BARRos, A. H. C. ; ARAújo FILHO, J. C. de; SilVA, A. B. da; SANTIAGO, G. A. C. F. Climatologia do Estado de Alagoas. Boletim de Pesquisa e Desenvolvimento, $n$. 211, 2012. 32 p. (Recife: Embrapa Solos).

CABRAL JÚNIOR, J. B.; BEZERRA, B. G. Análises da evapotranspiração de referência e do índice de aridez para o Nordeste do Brasil. Revista de Geociências do Nordeste-REGNE, Caicó, v. 4, n. 1, p. 71 - 89, 2018.

CARVALHo, H. de P.; DOURAdo NeTO, D.; TEOdORO, R. E. F; MELO, B. de. Balanço hídrico climatológico, armazenamento efetivo da água no solo $\mathrm{e}$ 
transpiração na cultura de café. Biociência Jornal, Uberlândia, v. 27, n. 2, p. 221229, 2011.

CAVALCANTI, E. P.; SILVA, V. de P. P.; SOUSA, F. de A. S. Programa computacional para a estimativa da temperatura do ar para a Região Nordeste do Brasil. Revista Brasileira de Engenharia Agrícola e Ambiental, Campina Grande, v. 10, n. 1, p. 140-147, 2006.

CONAMA. Resolução CONAMA no 238/1997: "Aprova Política Nacional de Controle da Desertificação". Data da legislação: 22/12/1997, Publicação DOU no 248, de 23/12/1997. Disponível

em: <http://www.mma.gov.br/port/conama/legiabre.cfm?codlegi=238>. Acesso em: 29 mai. 2017.

CUNHA, A. P. M. A.; ALVAlÁ, R. C. S.; KUBOTA, P. Y.; VIEIRA, R. M. S. P. Impacts of land use and land cover changes on the climate over Northeast Brazil. Atmospheric Science Letters, v. 16, p. 219-227, 2015. DOI: 10.1002/asl2.543.

EMBRAPA. Clima. Disponível em: <http://www.cnpf.embrapa.br/pesquisa/efb/clima.htm>. Acesso em: 29 mai. 2017.

FRANCISCO, P. R. M.; MEDEIROS, R. M. de; SANTOS, D.; MATOS, R. M. de. Classificação climática de Köppen e Thornthwaite para o estado da Paraíba. Revista Brasileira de Geografia Física, Recife, v. 8, n. 4, p. 1006-1016, 2015 a.

FRANCISCO, P. R. M.; MEDEIROS, R. M. de; MATOS, R. M. de; BANDEIRA, M. M.; SANTOS, D. Análise e mapeamento dos índices de umidade, hídrico e aridez através do BHC para o estado da Paraíba. Revista Brasileira de Geografia Física, Recife, v. 8, n. 4, p. 1093-1108, 2015b.

GUIMARÃES, S. O.; COSTA, A. A.; VASCONCELOS JÚNIOR, F. das C.; SILVA, E. M. da; SALES, D. S.; ARAÚJO JÚNIOR, L. M. de; SOUZA, S. G. de. Projeções de mudanças climáticas sobre o nordeste brasileiro dos modelos do CMIP5 e do CORDEX. Revista Brasileira de Meteorologia, São José dos Campos, v. 31, n. 3, p. 337-365, 2016. DOI: http://dx.doi.org/10.1590/0102-778631320150150.

INSA. Instituto Nacional do Semiárido. Disponível em: <https://portal.insa.gov.br/>. Acesso em: 21 mai. 2019.

LIMA, R. C. C.; CAVALCANTE, A. M. B. ; MARIN, A. M. P. Desertificação e mudanças climáticas no semiárido brasileiro. Campina Grande: Instituto Nacional do Semiárido-INSA, 2011. 209 p.

LOPES, I.; LEAL, B. G. Índice de aridez e tendência a desertificação para estações meteorológicas nos estados da Bahia e Pernambuco. Revista Brasileira de Climatologia, Curitiba, ano 11, v. 17, p. 155-172, 2015.

LOPES, I.; SANTOS, S. M. dos; LEAL, B. G.; MELO, J. M. M. de. Variação do índice de aridez e tendência climática à desertificação para a região semiárida do nordeste brasileiro. Revista Brasileira de Geografia Física, v. 10, n. 4, p. 10141026, 2017.

LUCENA, J. A. de; WANDERLEY, L. S. de A.; NÓBREGA, R. S. Risk desertification in Cabrobó/PE: climatic conditions and human activities. Revista Geama, v. 5, n. 1, p. 6-16, 2016. 
LUNDGREN, W. L. C.; SOUZA, I. F.de; AGUIAR NETTO, A. de O. Uso de distribuições de probabilidades para ajuste aos dados de precipitação mensal do estado de Sergipe. Revista Brasileira de Geografia Física, Recife, v. 8, n. 1, p. 71$80,2015$.

LUNDGREN, W. J. C.; SOUSA, I. F. de; LUNDGREN, G. A. Krigagem na construção de mapa pluviométrico do Estado de Sergipe. Revista Brasileira de Geografia Física, Recife, v. 10, n. 1, p. 13-22, 2017 a.

LUNDGREN, W. J. C.; SOUSA, I. F. de; LUNDGREN, G. A. Estimativa pluviométrica através das técnicas da krigagem e cokrigagem no Estado de Sergipe. Revista Brasileira de Geografia Física, Recife, v. 10, n. 3, p. 854-865, 2017b.

MATALLO JÚNIOR, H; SCHENKEL, C. S. (Org). Desertificação. Brasília: UNESCO, 2003.

MMA. Atlas das áreas susceptíveis à desertificação do Brasil. Marcos Oliveira Santana, organizador. Brasília: Ministério do Meio Ambiente, 2007. 134 p.

OYAMA, M. D.; NOBRE, C. A. A new climate-vegetation equilibrium state for Tropical South America. Geophysical Research Letter, v. 30, n. 23, p. 2199-2203, 2003. DOI: $10.1029 / 2003 G L 018600$

RIBEIRO, G. do N.; FRANCISCO, P. R. M.; PORTO, H. C.; ARAÚJO, J. S. O. de; SALES, J. C. R. de. Geotecnologias para o mapeamento temático dos índices de aridez e classes de desertificação na microrregião de Umbuzeiro-PB. Revista Técnico-Científica do CREA-PR, Curitiba, edição especial, p. 1-15, 2016.

SAMPAIO, E. V. S. B.; SAMPAIO, Y. S. B. Desertificação: conceitos, causas, consequências e mensuração. Recife: Universidade Federal de Pernambuco, 2002. $85 \mathrm{p}$.

SANTOS, S. M. dos; LEAL, B. G.; TAURA, T. A. Determinação da suscetibilidade climática à desertificação para os municípios baianos de Juazeiro, Casa Nova, Sobradinho e Curaçá. Revista OKARA: Geografia em debate, João Pessoa, v. 10, n. 1, p. 171-184, 2016.

SEMARH. Secretaria de Estado do Meio Ambiente e dos Recursos Hídricos. Atlas digital sobre recursos hídricos de Sergipe. Sistema de informações sobre recursos hídricos de Sergipe. Superintendência de Recursos Hídricos do Estado de Sergipe, versão 2012.9.

SILVA, C. J. da; FRANÇA, M. V. de; MEDEIROS, R. M. de; HOLANDA, R. M. de. O índice de aridez e sua tendência à desertificação na bacia do Rio Ipojuca-PE. Journal of Environmental Analysis and Progress, v. 4, n. 1, p. 21-30, 2019.

THORNTHWAITE, C. W; MATHER, J. R. Instructions and tables for computing potencial evapotranspiration and the water balance. New Jersey: Drexel Institute of Technogy, 1957. $180 \mathrm{p}$.

TOMASELLA, J.; VIEIRA, R. M. S. P.; BARBOSA, A. A.; RODRIGUEZ, D. A.; SANTANA, M. de O.; SESTINI, M. F. Desertification trends in the Northeast of Brazil over the period 2000-2016. International Journal of Applied Earth Observation and Geoinformation, v. 73, p. 197-206, 2018. DOI: https://doi.org/10.1016/j.jag.2018.06.012.

VIEIRA, R. M. S. P.; CUNHA, A. P. M. do A.; ALVALÁ, R. C. dos S.; CARVALHO, V. C.; FERRAZ NETO, S.; SESTINI, M. F. Land use and land cover map of a semiarid 
region of Brazil for meteorological and climatic models. Revista Brasileira de Meteorologia, v. 28, n. 2, p. 129-138, 2013.

VIEIRA, R. M. S. P.; TOMASELLA, J.; ALVALÁ, R. C. S.; SESTINI, M. F.; AFFONSO, A. G.; RODRIGUEZ, D. A.; CUNHA, A. P. M. A.; VALLES, G. F.; CREPANI, E.; OLIVEIRA, S. B. P. de; SOUZA, M. S. B. de; CALIL, P. M.; CARVALHO, M. A. de; VALERIANO, D. M.; CAMPELLO, F. C. B.; SANTANA, M. O. Identifying areas susceptible to desertification in the Brazilian northeast. Solid Earth, v. 6, p. 347360, 2015. DOI: $10.5194 /$ se-6-347-2015 